\title{
Formulation and evaluation of potash alum as deodorant lotion and after shaving astringent as cream and gel
}

\author{
*Abdulkarim K. Alzomor ${ }^{1}$, Ahmad Safe Moharram², Nahlah Mansour Al Absi² \\ ${ }^{1}$ Department of Pharmacy, Faculty of Medicine and health sciences, Thamar University, Republic of Yemen \\ ${ }^{2}$ Department of Medical Laboratories, Faculty of Medicine and health sciences, Thamar University, Republic of Yemen
}

\begin{abstract}
Potash alum has different traditional application including deodorant and astringent. In order to wide advancement in development of pharmaceutical and cosmetic industries we preferred to work in this field as well as for improvement of safety and efficacy of traditionally used natural products. The aim of the present study was to formulate deodorant potash alum as lotion dosage form and astringent as cream and gel dosage forms. The activity of potash alum against axillaries normal microbiota was tested in vitro using wells diffusion agar method for different concentrations $(0.1 \%$ to $9 \%)$ on Mueller Hinton (MH) agar and the minimum inhibitory concentration (MIC) was determined as $2 \%$ and also subculture was done to determine the activity of potash alum as bacteriostatic. Alum powder has wide traditional usage as astringent to prevent bleeding from minor cuts and for its accelerated healing. Therefore, a more appropriate dosage form was designed in a suitable concentration ( $2 \%$ gel) to elongate its astringent activity by its higher retention time due to highly viscous nature of gel. Using suitable excipients, $2 \%$ lotion and gel were prepared by dispersion method while emulsification was used for preparation of the potash alum cream of same strength. The above formulations were evaluated by comparing their $\mathrm{pH}$, viscosity, spreadability, contents uniformity and in vitro diffusion. The stability study was carried out at $25^{\circ} \mathrm{C}$ for 3 months and at $40^{\circ} \mathrm{C}$ with $75 \pm 5 \% \mathrm{RH}$ for one month. $\mathrm{pH}$, viscosity, spreadability, extrudability and consistency of the products were evaluated at the end of the studies. The results indicated no change in the formulations demonstrating their stable nature as a dosage form and suitability as a commercial product line.
\end{abstract}

Key Words: Alum, astringent, deodorant, formulation, stability.

\section{INTRODUCTION}

Dosage form is a drug delivery system designed to deliver the active ingredient to the body and, upon administration should deliver the drug at a rate and amount that assures the desired pharmacological effect. Topical dosage forms are applied to the skin and include ointments, pastes, creams, lotions, liniments, and transdermal patches (Marcel and Dekker, 2003). Natural products have been used for centuries in treating human diseases and they contain components of therapeutic value. Natural products are environmentally safer, easily available, and cheap (Osuala, 2009).

Alum occurs naturally in rocks that are located in areas where sulfide materials and potassium-bearing minerals. Alum (Aluminum potassium sulfate), the crystallized double sulfate with the formula $\mathrm{KAl}\left(\mathrm{SO}_{4}\right)_{2} .12 \mathrm{H}_{2} \mathrm{O}$, are generally odourless, colourless crystalline solids that turn white in air, which is used as an astringent and antisepsis in various food preparation processes such as pickling and fermentation and as a flocculants for water purification (Bestoon, 2012). Food and Drug Administration (FDAs) over the counter advisory panel has recommended alum as category I active ingredient in mouthwashes (Bestoon, 2012). Alum is used medicinally in many subunit vaccines as an adjuvant to enhance the body's response to immunogens; such vaccines include hepatitis A, hepatitis B (Doherty, 2005). Alum is also widely used in rural areas of Nigeria for the treatment of pediatric cough (Betsoon, 2012).

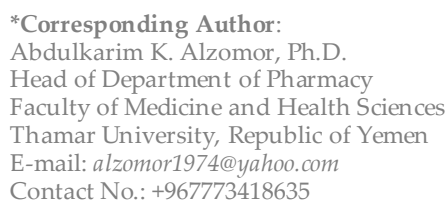

Styptic pencils containing aluminium sulfate or potassium aluminium sulfate are used as astringent to prevent bleeding from small shaving cuts. It was used as a base in skin whiteners and treatments during the late $16^{\text {th }}$ century.

\section{Deodorant action of potash alum}

A person's individual odour is determined genetically and can also be affected by food or medication (Kanalyavattanakul, 2011; Bhutta, 2007). Although sweating plays an important role, the classic association of sweat and body odour is only part of the explanation. It is true that unwanted body odour occurs mainly in the axilla (under arm) area and the feet but odour is only indirectly caused by secreted sweat. It is actually caused by bacteria living on the skin which find ideal conditions for growth in the warm areas of the body that tend to stay moist. These bacteria metabolise certain compounds Volatile Fatty Acids (VFAs) found in sweat, leading to the occurrence of unwanted body odour. The three most commonly used methods to deodorise (combat body odour) are to mask the smell with perfume, to reduce the quantity of sweat and to inhibit odour-producing bacteria (Benohanian, 2001).

Quantities of sweat can be reduced by using what are known as antiperspirants. In most cases these are metallic salts based on aluminium, zinc or manganese (Bhutta, 2007). The most frequently used antiperspirants are aluminium salts such as aluminium hydroxychloride, aluminium bromhydrate or aluminium sulphate. The volume of sweat produced is reduced by narrowing the sweat ducts. Antiperspirants form complexes with water, small scales of skin and lipids to create a protein mass which blocks the sweat glands. In this way the amount of sweat produced can be effectively but not permanently be reduced. Furthermore antiperspirants have astringent effects on skin, tightening the sweat glands which are 
further narrowed. Inhibition of body odour-causing bacteria is another important strategy for deodorisation. By inhibiting or deactivating odour producing bacteria, there is no or only slight metabolism of sweat components thus preventing/reducing the occurrence of body odour. The microorganisms present in the underarm area include Gram-positive bacteria of the Corynebacterium, Streptococcus, Propionibacterium and Micrococcus genera as well as yeast of the Malassezia genus. Bacteria responsible for production of body odour are Corynebacteria, Streptococci and Propionibacteria (Bhutta, 2007). A complete sterilisation of skin however should be avoided, as normal skin flora provides protection against bacterial infection caused by foreign pathogenic bacteria (Smits, 2012). Interestingly, Volatile fatty acids (VFAs) formation in the axilla is a dynamic process, with some cutaneous microorganisms, specifically Micrococci and Brevibacteria, capable of fully catabolizing these odorants. The results of these studies provide new understanding on the biochemical origins of VFA-based axillary malodour (James et al., 2004). Deodorant crystals containing synthetically made potassium alum are a weak irritant to the skin (Gallego et al., 1999).

\section{Astringent action of potash alum}

Astringent, is a group of substances that cause the contraction or shrinkage of tissues and that dry up secretions. Astringents are usually classified into three groups according to their mode of action: (a) those that decrease the blood supply by narrowing the small blood vessels (e.g. epinephrine and cocaine), (b) those that abstract water from the tissue (e.g., glycerol and alcohol), and (c) those that coagulate the superficial tissue layers into a crust (e.g., metallic astringents, such as calamine or alum). Astringent used in medicine to reduce swollen mucous membranes that result from inflammations of the nasal, gastrointestinal, and urinary passages, astringents are also frequently employed to dry up excessive secretions and (in this connection they are often known as styptics) to stop bleeding.

Alum in block form (usually potash alum) is used as astringent (British Pharmacopoeia, 2011). Alum acts only on the surface of cells and in the interstitial spaces. It has very low permeability into cells and little chance of systemic absorption (Levine, 1985). A final concentration of $1 \%$ is most commonly used and may be increased to $2 \%$ or $4 \%$ to achieve better response (Goel et al., 1985). Many cases reports describe treatment of hemorrhagic cystitis with alum (Goel et al., 1985; Ostroff, 1982; Arrizabalaga et al., 1987; Nina, 1997). Potassium alum molecules have a negative ionic charge, making it unable to pass through the cell wall and not absorbed. This is why these deodorants are safe to use and will not cause high levels of aluminum.

The goals for pharmaceutical research and development were set to enable the use of wider spectrum of active drugs as pharmaceuticals, improve the therapeutic efficacy of active drugs by new dosage forms, administration devices and targeting technologies and personalized medication, to increase user friendliness of pharmaceuticals and compliance by end users, and to enhance pharmaceutical industrial productivity, and to minimize illegal commercial activities. The safety and high relative efficacy of potash alum, at proper concentration rather than randomly wide traditional using it as deodorant and aftershave astringent, prepared as deodorant lotion and astringent cream and gel.
METHODS

Qualitative and quantitative evaluation

The physical tests such as appearance and organoleptic properties were done. Also $\mathrm{pH}$ was measured using calibrated $\mathrm{pH}$ meter and the melting point was measured by melting point apparatus.

The chemical test (Quantitative test) was done using compleximetric titration to aluminium in potash alum as follow: 1gm of the sample (alum) was weighed accurately by calibrated analytical electronic balance and dissolved in $50 \mathrm{ml}$ of water then, $50.0 \mathrm{ml}$ of $0.05 \mathrm{M}$ EDTA was added and boiled gently for $5 \mathrm{~min}$, after that the mixture was cooled and with continuous stirring, $20 \mathrm{ml}$ of $\mathrm{pH} 4.5$ buffer solution [77.1gm of ammonium acetate and $57 \mathrm{ml}$ of glacial acetic acid in $1000 \mathrm{ml}$ of D.W.]; $50 \mathrm{ml}$ of ethanol and $2 \mathrm{ml}$ of dithizone TS were added respectively and titrated with $0.05 \mathrm{M}$ zinc sulfate until bright rose pink colour was appeared. Each $\mathrm{ml}$ of $0.05 \mathrm{M}$ EDTA is equivalent to $12.91 \mathrm{mg}$ of $\mathrm{AlK}\left(\mathrm{SO}_{4}\right)_{2} .12 \mathrm{H}_{2} \mathrm{O}$ (British pharmacopoeia, 2011; US pharmacopoeia, 2007).

\section{In vitro biological activity study}

\section{Sample Collection}

Ten samples were collected from axilla of 5 healthy adult males using sterile cotton swab and transferred to the laboratory under cooling condition.

\section{Isolation of microorganisms}

The samples were streaked on ten nutrient agar plates (prepared according to manufacturer's instructions). Five of them were incubated under aerobic conditions (namely $1,2,3,4,5)$ and the others, were incubated under anaerobic conditions $(6,7,8,9,10)$ at $37 \pm 0.5^{\circ} \mathrm{C}$ for 24 hours, after that Gram stain for each colony were performed and observed under oily objective lens (100x) of compound microscope.

\section{Sub-culture preparation}

Subcultures from each growing colony were carried out on Nutrient agar plates and incubated at $37 \pm 0.5^{\circ} \mathrm{C}$ for 24 hours (one anaerobic" 6 " and four aerobic). After that one colony were taken from each subculture and stained with gram stain and observed under oily objective lens (100x) of compound microscope (Cleidson et al., 2007).

\section{Preparation of inoculums}

Mueller Hinton media were prepared according to manufacturer's instructions and one colony from each subculture plate as well as one fresh sample each one were taken and uniformly spreading by using sterile cotton swab on a sterile Petri dish MH agar (5 plates for each different subculture colony and for fresh sweat sample were prepared).

\section{Assay of antimicrobial activity}

Different concentrations of potash alum solutions were prepared (from $0.1 \%-9 \%$ ) and wells were made on Mueller Hinton media by cork-borer, (4 wells in each plate; $6 \mathrm{~mm}$ diameter holes were cut in the agar gel, $25 \mathrm{~mm}$ between one and another on agar). Each well was incorporated with $40 \mu \mathrm{L}$ of serially alum solution concentrations. The systems were incubated for $24 \mathrm{hr}$ at $37 \pm 0.5^{\circ} \mathrm{C}$, under aerobic $(1,41, \mathrm{~d} 1, \mathrm{Dx}$ and fresh) and anaerobic (6) conditions. After incubation, confluent bacterial growth was observed and the inhibition zone diameter was measured in $\mathrm{mm}$ and the minimum inhibitory concentration (MIC) was determined (Cleidson et al., 2007). 
Potash alum formulation

\section{Lotion preparation as deodorant}

The excipients and active pharmaceutical ingredient (API) were weighed accurately by calibrated analytical balance as showed in table 1. Required quantity of xanthan gum $(0.5 \mathrm{gm})$ was agitated in water until uniformly dispersed. Agitation was continued further for about 20 minutes. Then preservatives $(0.18 \mathrm{gm}$ of methyl paraben sodium and $0.02 \mathrm{gm}$ of propyl paraben sodium) were added to the lotion. Finally the lotion was neutralized by adding buffer components (1gm of citric acid monohydrate and 1.96gm of tri-sodium citrate) in water. $2 \mathrm{gm}$ of potash alum was dispersed in small amount of water and mixed with the lotion (Varun, 2012).

\section{Gel preparation as stringent}

The excipients and API were weighed accurately by calibrated analytical balance as showed in table 2 . Required quantity of Carbopol 974 (2.5gm) was agitated in water until uniformly dispersed. Agitation was continued further for about 20 minutes. Preservatives (0.18gm of methyl paraben sodium and $0.02 \mathrm{gm}$ of propyl paraben sodium) were added to the gel. Finally the gel was neutralized by adding buffer components $(0.1 \mathrm{gm}$ of citric acid monohydrate and $4 \mathrm{gm}$ of tri-sodium citrate) in water. 2gm of potash alum was dispersed in small amount of water and mixed with the gel (Varun, 2012).

\section{Cream $(\mathrm{O} / \mathrm{W})$ preparation as stringent}

Cream base was prepared by using emulsification technique (USP pharmacopoeia, 2007 and Forster et al., 1995). First, all excipients and API were weighed accurately by calibrated analytical balance as shown in table 3 . The oil phase was prepared where 30gm of emulsifying wax was heated until molten in water bath then $50 \mathrm{gm}$ of white soft paraffin was added to it and heated until molten after that $20 \mathrm{ml}$ of liquid paraffin was added to them with stirring, 30gm of oily phase was taken in flask and heated to $\left(60-70^{\circ} \mathrm{C}\right)$. The aqueous phase was prepared by dissolving the preservative $(0.18 \mathrm{gm}$ of methyl paraben sodium and $0.02 \mathrm{gm}$ of propyl paraben sodium) and $2 \mathrm{gm}$ of the API (potash alum) in $60 \mathrm{ml} \mathrm{D.W}$. then $0.5 \mathrm{ml}$ of tween 80 and $10 \mathrm{ml}$ of glycerin were added. Both phases (oily and aqueous) were heated up at the same temperature $\left(60-70^{\circ} \mathrm{C}\right)$ on water bath and the aqueous phase was added into the oily phase gradually with stirring. Finally, $0.5 \mathrm{ml}$ of rose oil was added into the mixture with continuous stirring until congeal.

\section{Accelerated stability study}

In the present study lotion, gel and cream formulations of potash alum has been formulated with effective concentrations (Syed et al., 2013). All formulations were divided into two samples, for each one three batches from each dosage form, separately and those samples were kept at different storage conditions i.e. at $25^{\circ} \mathrm{C}$ and at $40^{\circ} \mathrm{C}$ plus $75 \% \mathrm{RH}$ (relative humidity) with intensive light in stability chambers, and observed for a period of one month at definite time intervals. Stability studies were carried out for different formulations (lotion, cream and gel) according to International Conference on Harmonization $(\mathrm{ICH})$ guidelines. A sufficient quantity of each formula in suitable containers was stored in oven under $40 \pm 2^{\circ} \mathrm{C}$ and $75 \pm 5 \%$ RH for one month and all physical and chemical tests were done for the samples weekly through one month (Kuntal, 2012).
Table 1: Materials and their quantities used in lotion formulations.

\begin{tabular}{ll}
\hline Ingredient & Quantity \\
\hline Potash Alum & $2 \mathrm{gm}$ \\
Xanthan gum & $0.5 \mathrm{gm}$ \\
Methyl paraben Na & $0.18 \mathrm{gm}$ \\
Propyl paraben Na & $0.02 \mathrm{gm}$ \\
Citric acid. $\mathrm{H}_{2} \mathrm{O}$ & $1.5 \mathrm{gm}$ \\
Tri Na citrate. $2 \mathrm{H}_{2} \mathrm{O}$ & $3.5 \mathrm{gm}$ \\
Aqua & $100 \mathrm{ml}$ \\
\hline
\end{tabular}

Table 2: Materials and their quantities used in gel formulation.

\begin{tabular}{ll}
\hline Ingredient & Quantity \\
\hline Potash Alum & $2 \mathrm{gm}$ \\
Carbomere 974 & $2.5 \mathrm{gm}$ \\
Methyl paraben $\mathrm{Na}$ & $0.18 \mathrm{gm}$ \\
Propyl paraben $\mathrm{Na}$ & $0.02 \mathrm{gm}$ \\
Citric acid. $\mathrm{H}_{2} \mathrm{O}$ & $0.1 \mathrm{gm}$ \\
Tri Na citrate. $2 \mathrm{H}_{2} \mathrm{O}$ & $4 \mathrm{gm}$ \\
Aqua & $100 \mathrm{ml}$ \\
\hline
\end{tabular}

Table 3: Materials and their quantities used in cream (oil in water) formulation.

\begin{tabular}{ll}
\hline Ingredient & Quantity \\
\hline Potash Alum & $2 \mathrm{gm}$ \\
White soft paraffin & $50 \mathrm{gm}$ \\
Emulsifying wax & $30 \mathrm{gm}$ \\
Liquid paraffin & $20 \mathrm{ml}$ \\
Glycerin & $10 \mathrm{ml}$ \\
Tween 80 & $0.5 \mathrm{ml}$ \\
Methyl Paraben $\mathrm{Na}$ & $0.18 \mathrm{gm}$ \\
Propyl paraben $\mathrm{Na}$ & $0.02 \mathrm{gm}$ \\
Rose oil & $0.5 \mathrm{ml}$ \\
Aqua & $60 \mathrm{ml}$ \\
\hline
\end{tabular}

\section{Quality control of finished product \\ Physical evaluation}

All formulations of potash alum were evaluated for organoleptic properties, occlusiveness, washability by using usual methods but, viscosity, homogeneity and grittiness tests were done by using small quantity of product was pressed between the thumb and the index finger. The consistency and the texture of lotion, cream and gel were noticed. A small quantity of the sample was rubbed on the skin of the back of the hand to determine the homogeneity and spreadability. The spreadability is very important as show the behavior of gel and cream comes out from the tube (Sakura, 2000).

\section{pH Measurement}

Digital $\mathrm{pH}$ meter was used to determine the $\mathrm{pH}$ of the formulations (lotions, cream and gels) by immersing the electrode of $\mathrm{pH}$ meter in the samples and the results were recorded (Gupta, 2008).

Drug content measurement

Assay test was done to all formulations for potash alum using compleximetric titration method following US pharmacopoeia, (2007). 
Table 4: Figures show the morphological characteristics of bacterial isolated stain with Gram stain and examination under compound microscope.

\begin{tabular}{lll|l|l|l|l}
\hline Sample & $1^{*}$ (aerobic) & 6-* (anaerobic) & $41^{*}$ (aerobic) & $\mathrm{d}^{*}$ (aerobic) & Dx*(aerobic) & $\begin{array}{l}\text { Fresh sample } \\
\text { (aerobic) }\end{array}$ \\
\hline $\begin{array}{l}\text { Gram stain } \\
\text { differe- } \\
\text { ntiation }\end{array}$ &
\end{tabular}

$1^{*}, 6^{*}, 41^{*}, \mathrm{~d} 1^{*}, \mathrm{Dx} *$ isolated bacteria codes

Table 5: Results of antibacterial activity of potash alum.

\begin{tabular}{|c|c|c|c|c|c|c|}
\hline \multirow{2}{*}{$\begin{array}{c}\text { Alum } \\
\text { Conc. } \%\end{array}$} & \multicolumn{6}{|c|}{ Inhibition diameter (mm) } \\
\hline & $1^{*}$ (aerobic) & 6-* (anaerobic) & Dx* (aerobic) & d1* (aerobic) & $41^{*}$ (aerobic) & Fresh sample (aerobic) \\
\hline 0.1 & - & - & - & - & - & - \\
\hline 0.2 & - & - & - & - & - & - \\
\hline 0.3 & - & - & - & - & - & - \\
\hline 0.4 & - & - & - & - & - & - \\
\hline 0.5 & - & - & - & - & - & - \\
\hline 0.6 & - & - & - & - & - & - \\
\hline 0.7 & - & - & - & - & - & - \\
\hline 0.8 & - & - & - & - & - & - \\
\hline 0.9 & 7 & - & - & - & - & - \\
\hline 1 & 9 & 8 & - & - & - & - \\
\hline 2 & 10 & 11 & 10 & 9 & 10 & 8 \\
\hline 3 & 11 & 12 & 12.5 & 10.5 & 11 & 9 \\
\hline 4 & 12.5 & 14 & 13 & 13 & 12 & 11 \\
\hline 5 & 13 & 15 & 15 & 14 & 14 & 12 \\
\hline 6 & 14 & 16 & 17 & 16 & 15 & 12.5 \\
\hline 7 & 15 & 16.5 & 18 & 16.5 & 16 & 13 \\
\hline 8 & 14 & 18 & 14 & 17 & 17 & 16 \\
\hline 9 & 15.5 & 19 & 16 & 18 & 19 & 17 \\
\hline
\end{tabular}

$1^{*}, 6-^{*}, 41^{*}, \mathrm{~d} 1^{*}, \mathrm{Dx} *$ isolated bacteria codes

Table 6: Test results of lotion, gel and cream under control and stressed conditions at different time points.

\begin{tabular}{|c|c|c|c|c|c|c|c|c|c|c|c|c|c|}
\hline \multirow{2}{*}{$\begin{array}{l}\text { Time } \\
\text { period }\end{array}$} & \multirow{2}{*}{$\begin{array}{c}\text { Temp. } \\
\text { RH }\end{array}$} & \multirow[t]{2}{*}{ B.N } & \multicolumn{2}{|c|}{ Lotion } & \multicolumn{2}{|c|}{ Gel } & \multicolumn{2}{|c|}{ Cream } & \multicolumn{5}{|c|}{ Parameters } \\
\hline & & & Assay & $\mathrm{pH}$ & Assay & $\mathrm{pH}$ & Assay & $\mathrm{pH}$ & Viscosity & Spread. & Wash. & Homogeneity & Odor \\
\hline \multirow[t]{3}{*}{0 day } & $25^{\circ} \mathrm{C}$ & 1 & 98.2 & 3.40 & 98.7 & 3.76 & 98.2 & 3.40 & Good & Good & Easy & Good & $\mathrm{NC}$ \\
\hline & $65 \%$ & 2 & 99.5 & 3.36 & 98.4 & 3.79 & 99.5 & 3.36 & Good & Good & Easy & Good & $\mathrm{NC}$ \\
\hline & & 3 & 98.9 & 3.36 & 98.9 & 3.83 & 98.9 & 3.36 & Good & Good & Easy & Good & $\mathrm{NC}$ \\
\hline \multirow[t]{6}{*}{$1^{\text {st }}$ week } & $25^{\circ} \mathrm{C}$ & 1 & 98.5 & 3.41 & 98.7 & 3.81 & 98.5 & 3.41 & Good & Good & Easy & Good & $\mathrm{NC}$ \\
\hline & $65 \%$ & 2 & 98.8 & 3.33 & 98.4 & 3.83 & 98.8 & 3.33 & Good & Good & Easy & Good & $\mathrm{NC}$ \\
\hline & & 3 & 98.4 & 3.35 & 99.0 & 3.90 & 98.4 & 3.35 & Good & Good & Easy & Good & $\mathrm{NC}$ \\
\hline & $40^{\circ} \mathrm{C}$ & 1 & 98.0 & 3.40 & 97.9 & 3.79 & 98.0 & 3.40 & Good & Good & Easy & Good & NC \\
\hline & $75 \pm 5 \%$ & 2 & 97.9 & 3.37 & 98.3 & 3.86 & 97.9 & 3.37 & Good & Good & Easy & Good & NC \\
\hline & & 3 & 98.0 & 3.35 & 98.9 & 3.85 & 98.0 & 3.35 & Good & Good & Easy & Good & NC \\
\hline \multirow[t]{6}{*}{$2^{\text {nd }}$ week } & $25^{\circ} \mathrm{C}$ & 1 & 98.1 & 3.51 & 98.6 & 3.82 & 98.1 & 3.51 & Good & Good & Easy & Good & NC \\
\hline & $65 \%$ & 2 & 97.9 & 3.32 & 98.4 & 3.77 & 97.9 & 3.32 & Good & Good & Easy & Good & NC \\
\hline & & 3 & 98.1 & 3.43 & 98.6 & 3.84 & 98.1 & 3.43 & Good & Good & Easy & Good & $\mathrm{NC}$ \\
\hline & $40^{\circ} \mathrm{C}$ & 1 & 97.9 & 3.48 & 97.9 & 3.77 & 97.9 & 3.48 & Good & Good & Easy & Good & NC \\
\hline & $75 \pm 5 \%$ & 2 & 97.8 & 3.34 & 98.3 & 3.80 & 97.8 & 3.34 & Good & Good & Easy & Good & $\mathrm{NC}$ \\
\hline & & 3 & 98.2 & 3.39 & 98.1 & 3.86 & 98.2 & 3.39 & Good & Good & Easy & Good & NC \\
\hline \multirow[t]{6}{*}{$3^{\text {rd }}$ week } & $25^{\circ} \mathrm{C}$ & 1 & 98.2 & 3.49 & 98.2 & 3.76 & 98.2 & 3.49 & Good & Good & Easy & Good & NC \\
\hline & $65 \%$ & 2 & 97.7 & 3.33 & 98.4 & 3.79 & 97.7 & 3.33 & Good & Good & Easy & Good & NC \\
\hline & & 3 & 98.0 & 3.36 & 98.1 & 3.82 & 98.0 & 3.36 & Good & Good & Easy & Good & NC \\
\hline & $40^{\circ} \mathrm{C}$ & 1 & 98.3 & 3.52 & 97.9 & 3.87 & 98.3 & 3.52 & Good & Good & Easy & Good & NC \\
\hline & $75 \pm 5 \%$ & 2 & 97.9 & 3.37 & 98.0 & 3.81 & 97.9 & 3.37 & Good & Good & Easy & Good & NC \\
\hline & & 3 & 98.2 & 3.40 & 98.2 & 3.86 & 98.2 & 3.40 & Good & Good & Easy & Good & $\mathrm{NC}$ \\
\hline \multirow[t]{6}{*}{$4^{\text {th }}$ week } & $25^{\circ} \mathrm{C}$ & 1 & 97.8 & 3.47 & 98.1 & 3.79 & 97.8 & 3.47 & Good & Good & Easy & Good & $\mathrm{NC}$ \\
\hline & $65 \%$ & 2 & 97.9 & 3.38 & 98.2 & 3.90 & 97.9 & 3.38 & Good & Good & Easy & Good & $\mathrm{NC}$ \\
\hline & & 3 & 98.1 & 3.38 & 98.2 & 3.82 & 98.1 & 3.38 & Good & Good & Easy & Good & NC \\
\hline & $40^{\circ} \mathrm{C}$ & 1 & 97.6 & 3.49 & 97.9 & 3.87 & 97.6 & 3.49 & Good & Good & Easy & Good & $\mathrm{NC}$ \\
\hline & $75 \pm 5 \%$ & 2 & 97.8 & 3.40 & 98.3 & 3.81 & 97.8 & 3.40 & Good & Good & Easy & Good & NC \\
\hline & & 3 & 97.7 & 3.39 & 97.9 & 3.79 & 97.7 & 3.39 & Good & Good & Easy & Good & $\mathrm{NC}$ \\
\hline
\end{tabular}

*B.N.: Batch number, ${ }^{*}$ RH: Relative humidity, ${ }^{*}$ Temp.: Temperature, *Spread.: Spreadability. ${ }^{*}$ NC: no change *Wash.: Washability. 


\section{Microbiological test}

Nutrient agar was prepared (according to manufacturer's instructions) by dispersing $28 \mathrm{~g}$ in $1000 \mathrm{ml}$ of distilled water and heat to boiling then sterilize by autoclaving, after that small amount from each prepared formula was taken and cultured in the nutrient agar and incubated at $37^{\circ} \mathrm{C}$ for 24 hours and the result was recorded.

\section{RESULTS AND DISCUSSION}

\section{Quality evaluation}

Physical tests showed that the potash alum tested was colourless, transparent, odourless and octahydral crystalline masses. The $\mathrm{pH}$ was 3 for $10 \%$ of potash alum solution and melting point was equal $92^{\circ} \mathrm{C}$. Chemical tests of potash alum: Quantitative estimation for potash alum sample using compleximetric titration was equal to $99.9 \%$.

\section{In vitro antimicrobial activity}

The microscopical observation of inoculated nutrient agar plates were five different colonies (one anaerobic " 6 " and four aerobic "1, 41, Dx, d1") showed the growth of different gram positive normal flora bacteria colonies. Gram positive bacteria was recognized by gram stain and classified morphologically into: Staphylococcus spp. (with streaking mainly appeared as diplococcus spp.)(1), streptobacillus spp. (two spp.)(6-)(4l), single bacilli spp. (two spp.)(dl)(Dx). The microscopical observation of subcultured plates showed the growth of gram positive bacteria of staphylococcus spp,micrococcus spp., corynebacterium spp. and propionibacterium spp. colonies that present on skin as normal flora which were confirmed by the staining method and illustrated in figures in table 4.

Although epidemiological studies (Kelber et al., 1984), have demonstrated the antibacterial activity of aluminium and several possible mechanisms of action have been suggested, no study, as yet, has conclusively proved the mechanism of action of Aluminium (Mourghan, 2004). Though antibacterial effect of aluminium solution are discussed by many authors (Olmez, 1998 and Olsson et al., 1978) citing various mechanisms in the present study two factors gain importance: Auminium in alum solutions is a tri-valent ion (Simonsson et al., 1988) and the $\mathrm{pH}$ of alum solutions (Olsson et al., 1977).

The present study revealed that the alum has bacteriostatic activity against axillary normal bacterial flora (table 5). The minimum inhibition concentration (MIC) was observed at concentration $2 \%$ of alum solution for most of isolated genus but for Staphylococcus spp. and anaerobic Streptobacillus spp. the MIC was observed at $0.9 \%$ and $1 \%$ respectively. The diameter of inhibition zone was increased with increasing of concentrations to $9 \%$ of potash alum stock solutions.

Diffusion well-variant method also carried out for lotion samples for $2 \%$ with different $\mathrm{pH}$ value by modifying of buffer soln. component concentrations in lotion as a result the diameter of $2 \%$ lotion with $\mathrm{pH}=4$ was observed $13 \mathrm{~mm}$ as well as $12 \mathrm{~mm}$ for $2 \%$ lotion with $\mathrm{pH}=3$ but for concentration $6.5 \%$ (Sarfaraz and Niazi, 2004 ) the diameter was observed $15 \mathrm{~mm}$; so that $2 \%$ lotion formulation, that has relative high $\mathrm{pH}$ value closer to skin secretion $\mathrm{pH}$ was selected to improve antibacterial activity (Mourghan, 2004) of product and the alum more stable at pH values (2.5 to 4.4) (Putt et al., 1985).

\section{Stability study}

The alum lotion, gel and cream were prepared and subjected to evaluation of the various parameters. The results of the lotion, gel were transparent and cream were creamy white in color and pearl like appearance and gave cool and smooth feel on application which was maintained after tested the stability study (Kuntal, 2012). The initial viscosity of formulated alum was showed constant stability in comparison with after accelerated stability study performed. Further 3 months stability study was carried out at normal room temperature $\left(25^{\circ} \mathrm{C}\right)$ but results were unchanged. The drug content of all preparations were estimated by compleximetric titration were found to be uniform among various formulations prepared and was found to range from 97.6 to $99.9 \%$ as shown in table 6 , also showed that the drug was uniformly distributed throughout all preparations.

The $\mathrm{pH}$ of human skin typically ranges from 4.0 to 6.0 (Issa et al., 2000). Therefore, the formulations intended for application to skin should have $\mathrm{pH}$ closer to this range (Akhtar et al., 2011). In this study, the $\mathrm{pH}$ values of samples of formulations kept at $25^{\circ} \mathrm{C}$ and $\left(40^{\circ} \mathrm{C}\right.$ with $75 \%$ $\mathrm{RH})$ were shown weak acidity with no significant difference with all the formulated batches (3.68-3.82) for lotion, (3.71-3.90) for gel and (3.32-3.52) for cream.

None of the lotion formulations showed changes in the odor, appearance, color and transparency during the one month of accelerate stability testing. Furthermore, there was an insignificant difference among all the formulated lotions in terms of $\mathrm{pH}$, viscosity, spreadability and drug content through accelerated stability testing period so, that lotion formulations were fairly stable as shown in table 6 (Syed et al., 2013). Also gel formulations showed good homogeneity, smooth and texture, transparent in nature, good in appearance, viscosity, odorless. Spreadability and homogeneity gel upon preparation were accepted, which exhibited a suitable $\mathrm{pH}$ values with no significant difference with different gel batches as shown in table 6.

The formulated alum cream, as shown in table 6, revealed good physical stability including easy to wash, non-greasy with good stable spreadability and smooth texture with no creaming, coalescence or liquification occur through analysis period of accelerated stability study. The components of oil phase i.e. paraffin oil which is a colorless, transparent, tasteless, non-fluorescent liquid; and is mixture of hydrocarbons (Henriette, 1995). Viscosity is a useful process indicator of emulsion quality, as it is highly sensitive to changes in the emulsion due to variations in process and formulation parameters (Ronald et al., 1994). As soon as an emulsion has been prepared, time and temperature-dependent processes occur to effect its separation leading to the decreased viscosity which results in increased liquefaction (Herbert et al., 1998). No liquefaction was observed in any of the sample of formula kept at $25^{\circ} \mathrm{C}$ and $40^{\circ} \mathrm{C} \& 75 \% \mathrm{RH}$ during whole observation period of one month.

\section{Microbial test}

All batches for each dosage form conformed pharmacopoeial requirements of microbial test (not more than $10^{2}$ $\mathrm{CFU} / \mathrm{ml}$ for fungi and not more than $10^{3} \mathrm{CFU} / \mathrm{ml}$ for bacteria) under suitable aerobic and anaerobic conditions in incubator.

\section{CONCLUSION}

Potash alum is an Alum, inorganic chemical substance refers to any of a group of hydrated double salts results from the hydration of the sulfate of a singly charged cation $\left(e . g ., \mathrm{K}^{+}\right)$and the sulfate of any one of a number of triply charged cations $\left(e . g ., \mathrm{Al}^{3+}\right)$. Natural alum stone is a translucent crystalline colorless stone, used topically to 
perform antibacterial and astringent action. In the present study, an attempt was made to formulate topical lotion, cream and gel of potash alum to act deodorant and astringent activity respectively.

Lotion, cream and gel are prepared at effective concentration $2 \%(\mathrm{w} / \mathrm{v})$ for lotion, cream and gel by dispersion for lotion and gel and emulsification for cream using different excipients. These topical formulations were tested for $\mathrm{pH}$, viscosity, spreadability, drug contents uniformity, in vitro diffusion. The stability study was carried out at 25 and $40^{\circ} \mathrm{C}$ with $75 \pm 5 \% \mathrm{RH}$ for one month. All formulations were found to have satisfactory firmness.

\section{ACKNOWLEDGEMENT}

Authors are thankful to Pharmacy Department, Thamar University, General Thamar Hospital Laboratory and Global Pharmaceutical Company in Yemen for providing the facilities for completion the work.

\section{REFERENCES}

Akhtar N, et al., (2011). Formulation Development and Moiturising Effects of a Topical Cream of Aloe vera Extract, World Academy of Science, Engineering and Technology 51, p.172-179

Arrizabalaga M., et al. (1987).Treatment of massive haematuria with aluminous salts. Br J Urol ; 60: 223 \pm 6 .

Benohanian A. (2001). Antiperspirants and deodorants. Clin Dermatol; 19(4):398-405. [DOI]

Bestoon M., (2012), M.Sc. PhD. Evidence for feasibility of aluminum potassium sulfate (alum) solution as a root canal irrigant, J Bagh College Dentistry Vol. 24 (special issue 1)

Bhutta MF. (2007). Sex and the nose: human pheromonal responses. J R Soc Med.; 100(6): 268-274. [DOI]

British pharmacopoeia, volume I\&II, 2011.

Choong S.K.S., Walkden M. and Kirby R. (2000). The management of intractable haematuria. St. George's Hospital, Blackshaw Road, London, UK. BJU International, 86(9): 951-959. [DOI]

Cleidson Valgas et al., (2007). screening methods to determine antibacterial activity of natural products, Universidade do Sul de Santa Catarina, Tubarão, SC, Brasil; Brazilian Journal of Microbiology ; 38:369-380 ISSN 1517-8382.

Doherty, T.M. and P. Anderson, (2005). Vaccines for tuberculosis: novel concepts and recent progress. Clinical microbiology reviews, 18: 687702. [DOI]

Forster T., et al.(1995).Influence Of Microemulsion Phases on the Preparation Of Fine Disperse Emulsions.

Gallego H, et al., (1999). "Crystal deodorant dermatitis: irritant dermatitis to alum-containing deodorant". Cutis 64 (1): 65-6.

Gaswami AK., et al. (1993); How safe is 1\% alum irrigation in controlling intractable vesical hemorrhage?,149:264-7.

Goel AK, et al., (1985) Intravesical irrigation with alum for the control of massive bladder hemorrhage. J Urol ; 133: 956-7.[ v.16(4); Oct-Dec 2009]

Gupta M, Verma PRP, Marwaha RK, Faruk A, Singh G. J Pharm Res, 2008; 7:27-31.

Henriette K.1995, Liquid Paraffin. The BP Codex: 1911.

Herbert A L., et al. (1988). Pharmaceutical Emulsions, Pharmaceutical Dosage Forms: Disperse System. Vol.1, Marcel Dekkar, New York and Basel: 199-240, 285-288.

Issa T S. et al. (2000). Improved kinetic parameter estimation in $\mathrm{pH}$-profile data treatment, International Journal of Pharmaceutics: 198, 39-49. [DOI]
James A.G.,et al.(2004). Unilever R \& D colworth, colworth house, sharnbrook, Bedford MK44 ILQUK. world journal of microbiology \& biotechnology20: 787-793.

Kanlayavattanakul M., Lourith N.(2011). Body malodours and their topical treatment agents. Int J Cosmet Sci., 33(4):298-311. [DOI]

Kelber CJ and Putt MS, (1984). Alum and dental caries - a review of the literature. Clinprev dent, 6(6); 14-25.

Kuntal Das, Raman Dang, et al. (2012). Evaluation for safety assessment of formulated vanishing cream containing aqueous Stevia extract, Indian Journal of Novel Drug Delivery 4(1), Jan-Mar, 43-51.

Levine LA, Richie JP. (1985). Urological complications of cyclophosphamide. J Urol;141:1063-9.

Marcel Dekker. (2003); INC. 270 Madison Avenue New York, NY 10016.

Mourghan k, and Suryakan TH M P. (2004); Evaluation of an alum containing mouth rinse for inhibition of streptococcus mutans level in children, collage of dental surgery, Mangalore, Manipal academy of higher education, Indian: 22(3) 100-105.

Nina J. West. (1997). Prevention and Treatment of Hemorrhagic Cystitis, College of Pharmacy, University of Michigan, Ann Arbor, Michigan. UHB2D301 Box 0008, 1500 East Medical Center Drive, Ann Arbor, MI 48109-0008. Pharmacotherapy; 17(4):696-706.

Olmez A,Can H, Ayhan $\mathrm{H}$ and Olur H.(1998). Effect of alum containing mouth rinse in children for plaque and salivary levels of selected oral microflora, J Clinpediatr Dent, 22(4): 335-41.

Olsson J and Adham G. (1978). Effect of inorganic ions \& surface active organic compounds on adherence of oral streptococci: Scand J Dent Res, 86, 108-17.

Olsson J and Glantz PO. (1977). Effect of $\mathrm{pH}$ and counter ions the zetapotential of oral streptococci. Arch oral Biol, 22: 461-6. [DOI]

Ostroff EB, Chenault OW Jr. (1982). Alum irrigation for the control of massive bladder hemorrhage. J Urol ; 128: 929-30

Osuala F.I., (2009); Evaluation of the Efficacy and Safety of alum in the Treatment of Tuberculosis, Ecotoxicology Laboratory, Department of Zoology, University of Lagos, Nigeria, European J. of Biol. Sci., 1 (1): $10-14$

Putt MS and Kelber CJ (1985): Dissolution studies of human enamel treated with aluminium solutions, J Dent Res; 64(3):437-40. [DOI

Ronald M B and Thomas F B. (1994). Use of viscosity as an in-line diagnostic for high internal phase emulsion generation, US Patent 5306734.

Sakurai. K., Maegawa. T., Takahashi. T.(2000); Glass transition temperature of chitosan and miscibility of chitosan/poly (Nvinylpyrrolidone) blends. Polymer, 41, 7051-7056. [DOI]

Sarfaraz K. Niazi,(2004) Handbook of Pharmaceutical Manufacturing Formulations, formulation of semi solids, vol 4.

Simonsson T, Glantz PO and Edwardssons:(1988). Effects of cations on the colloidal stability of some oral bacteria. Actaodoutal Scand; 46: 83-7.

Smits J., B. Senti, N. (2012) Herbst, Potassium alum dodecahydrate/[the merck index. 10th ed. Rahway, new jersey: merck co., inc., 1983., p. 53. Cosmetochem International AG, Steinhausen /ZG, Switzerland. Cosmotic Drug Technology.

Syed Nisar, Hussain Shah, et al. (2013). Formulation Study of Topically Applied Lotion: In Vitro and in vivo evalution, Faculty of Pharmacy, Bahauddin Zakariya University, Multan, Pakistan; BioImpacts, 3(1), 11 19. [ Bioimpacts > v.3(1); 2013]

United States Pharmacopoeia (2007)

Varun Thakur, (2012). Formulation and in vitro Evaluation of Gel for Topical Delivery of Antifungal Agent Fluconazole. Department of Pharmaceutics, Manav Bharti University, Village Laddo, Tehsil \& Distt. Solan, HP, India, 173229 